\title{
INTER AND INTRA ROW COMPETITION EFFECTS ON GROWTH AND YIELD COMPONENTS OF SUNFLOWER (HELIANTHUS ANNUUS L.) UNDER RAINFED CONDITIONS
}

\author{
İ. Demir \\ Kırşehir Ahi Evran University, Faculty of Agriculture, Department of Field Crops, Kırşehir, Turkey \\ Corresponding Author's Email: ismail.demir@ahievran.edu.tr
}

https://doi.org/10.36899/JAPS.2020.1.0017

Published online January 02, 2020

\begin{abstract}
Sunflower (Helianthus annuus L.) is an important oilseed plant with high adaptability to semi-arid conditions for reasonable vegetable oil production. The aim of this study was to determine the agronomic responses of Bosfora hybrid sunflower cultivar sown inter-row $(50$ and $70 \mathrm{~cm}) \&$ intra-row $(20,25,30,35$ and $40 \mathrm{~cm})$ spacing in rainfed conditions. The field experiment was laid out on split plots in randomized blocks with three replications for two years (2016 and 2017). Inter row spacings were placed in the main plots and intra row spacings were placed in the subplots. Narrower inter-row $(50 \mathrm{~cm})$ and intra-row $(20$ and $25 \mathrm{~cm})$ plant spacing caused taller plant development but decreased stem thickness, head diameter, thousand-seed weight, number of seeds in a head, dehulled seed ratio, seed weight of per plant, crude oil ratio, day to flowering and maturity. The highest yield $\left(2759.9 \mathrm{~kg} \mathrm{ha}^{-1}\right)$ was obtained in $50 \times 20 \mathrm{~cm}$ spacing while the lowest $\left(1963.8 \mathrm{~kg} \mathrm{ha}^{-1}\right)$ yield was obtained in $70 \times 20 \mathrm{~cm}$ spacing, more likely, due to the increase in the number of plants per unit area. The crude oil ratio was decreased by narrower spacing. However, oil yield was increased with seed yield $\left(\mathrm{kg} \mathrm{ha}^{-1}\right)$ and reached the highest amounts (1221.9 and $\left.844.2 \mathrm{~kg} \mathrm{ha}^{-1}\right)$ in narrow row spacing, attributed to the plant population per unit area. To conclude that the highest seed yield was obtained from narrower $(50 \times 20 \mathrm{~cm}$ and $50 \times 25$ $\mathrm{cm})$ seeding rates in rainy year (2016), while the highest yields were obtained from lowest plant population $(70 \times 20$ and $70 \times 25 \mathrm{~cm})$ rates in dry year (2017).
\end{abstract}

Keywords: arid, row spacing, oil yield, sunflower, yield.

\section{INTRODUCTION}

The increase in world population and demand for changes in dietary habits are only attainable with optimum utilization of agricultural areas and maximum efficiency in cultivated lands. A wide range of agronomic studies conducted, primarily in breeding studies, has led to a significant increase in agricultural production. However, in addition to improving high yielding varieties to obtain higher yield, further studies have been needed to determine the appropriate soil, climate conditions and cultivation techniques by investigating the yield characteristics of varieties and testing their performances under different environmental conditions. Agronomic practices in sunflower, in addition to high-yielding hybrid varieties, are important management decisions for increasing the yield per unit area (Beg et al., 2007). The number of plants per unit area is one of most important agronomic practice affecting the yield in sunflower (Ahmad et al., 2010). However, this component of yield may vary dependent on the environmental conditions. Higher seed yield per plant can be obtained only by decreasing plant density due to the increased interland competition for light and other factors (Diepenbrock et al., 2001). Further increase in plant density may lead to a stable and even reduced seed yield affected by environmental factors (Ion et al., 2015). The results on the highest yield and the plant density reported from different parts of the world are contradictory to each other. The higher yields were obtained by 100 thousand plants ha $^{-1}$ (Esechie et al., 1996; Beg et al., 2007). However, different densities have been reported in different areas ranging from 45 to 75 thousand $\mathrm{ha}^{-1}$. The differences in plant density may cause the significant agronomic results in semi-arid ecological conditions. Plant density and land usage has great importance for industrial plants such as canola and sunflower etc.

Sunflower has been an important oilseed crop to meet the vegetable oil demands of Turkey due to the high drought tolerance and sufficient yield in non-irrigated areas (Demir and Basalma, 2018). The use of hybrid seeds recently has increased the yield and oil production per unit area. The increase had positive influence on preference of producers and, also, played a significant role in meeting the vegetable oil demand of Turkey. This study aimed to determine the changes in plant growth, yield and yield parameters of sunflower sown in different inter-row and intra-row spacing in semi-arid ecological conditions. The plant density per unit area is an important factor affecting seed yield and, consequently, oil yield in 
arid conditions along with irregular and inadequate precipitation. Determining the highest yielding sunflower population per unit area will play an important role in providing economic and sustainable agriculture as well as meeting the demand for vegetable oil.

\section{MATERIALS AND METHODS}

This study was conducted in Research Farm of Agricultural Faculty of Kırşehir Ahi Evran University in 2016 and 2017. Bosfora oilseed sunflower (Helianthus annuus L.) cultivar was used as plant material. This experimental field in Kırşehir province is located at $39.15^{\circ}$ Northern latitude and $34.11^{\circ}$ Eastern longitude at 1014 meters above sea level. Experimental soil of field has clayed loam texture, alkaline character, calcareous, non-saline, has certain amount of available phosphorus concentration, rich in potassium content, poor in organic matter and nitrogen (Table 1).
The field experiment was conducted on split plots in randomized blocks with three replications for two years. Row spacings $(50$ and $70 \mathrm{~cm}$ ) were placed in the main plots and intra-row spacing $(20,25,30,35$ and 40 $\mathrm{cm})$ were placed in the subplots. Experimental design, plant density and the number of sown seeds are given in Table 2 .

Sunflower seeds were sown in the second week of April (10.04.2016 and 14.04.2017) considering the suitable weather conditions. Nitrogen and phosphorus were applied at a rate of $100 \mathrm{~kg} \mathrm{~N} \mathrm{ha}^{-1}$ and $80 \mathrm{~kg} \mathrm{P}_{2} \mathrm{O}_{5} \mathrm{~kg}$ $\mathrm{ha}^{-1}$, respectively, based on soil analyses of experimental field. Half of nitrogen along with full dose of phosphorus was applied at sowing, and remaining half of nitrogen was applied at 6-8 leaf stage as broadcasting. The flowering date, harvest time, plant height, stem thickness, head diameter, number of seeds in a head, seed weight in a head, thousand-seed weight, yield, crude oil ratio (Soxhlet extract method) and oil yield values were determined.

Table 1. Soil characteristics of experimental field.

\begin{tabular}{cccccccc}
\hline Texture & PH & $\begin{array}{c}\text { EC } \\
(\mathbf{m m h o s} / \mathbf{c m})\end{array}$ & $\begin{array}{c}\text { Salinity } \\
(\mathbf{\%})\end{array}$ & $\begin{array}{c}\text { Available } \mathbf{P}_{2} \mathbf{O}_{\mathbf{5}} \\
\left(\mathbf{k g ~ h a}^{-1}\right)\end{array}$ & $\mathbf{C a C O}_{\mathbf{3}}(\mathbf{\%})$ & $\begin{array}{c}\text { Available } \mathbf{K}_{\mathbf{2}} \mathbf{O} \\
\left(\mathbf{k g ~ h a}^{-1}\right)\end{array}$ & $\begin{array}{c}\mathbf{O M} \\
(\mathbf{\%})\end{array}$ \\
\hline Clayed-Loamy & 7.49 & 0.57 & 0.02 & 26.7 & 27.43 & 796.2 & 1.69 \\
\hline
\end{tabular}

Table 2. Average plant population density and seeding rate for different inter row and intra row spaces.

\begin{tabular}{llll}
\hline Inter row spaces (cm) & Intra row spaces $(\mathbf{c m})$ & Plant density $\left(\right.$ plant ha $\left.^{-\mathbf{1}}\right)$ & Seeding rate $\left(\mathbf{k g ~ h a}^{\mathbf{- 1}}\right)$ \\
\hline \multirow{4}{*}{$\mathbf{5 0}$} & 20 & 100000 & 8.42 \\
\hline 25 & 80000 & 6.75 \\
\hline 30 & 66660 & 5.65 \\
\hline 35 & 57400 & 4.85 \\
\hline \multirow{3}{*}{$\mathbf{7 0}$} & 20 & 50000 & 4.25 \\
\hline & 25 & 71430 & 6.05 \\
\hline 30 & 57140 & 4.85 \\
\hline
\end{tabular}

Table 3. Meteorological data for experimental location during growing season.

\begin{tabular}{|c|c|c|c|c|c|c|c|c|c|c|}
\hline \multirow[t]{2}{*}{ Parameter } & \multicolumn{6}{|c|}{ Temperature $\left({ }^{\circ} \mathbf{C}\right)$} & \multirow{2}{*}{\multicolumn{2}{|c|}{$\begin{array}{c}\text { Relative } \\
\text { Humidity (\%) }\end{array}$}} & \multirow{2}{*}{\multicolumn{2}{|c|}{$\begin{array}{l}\text { Precipitation } \\
(\mathbf{m m})\end{array}$}} \\
\hline & \multicolumn{2}{|c|}{ Maximum } & \multicolumn{2}{|c|}{ Minimum } & \multicolumn{2}{|c|}{ Mean } & & & & \\
\hline Month & 2016 & 2017 & 2016 & 2017 & 2016 & 2017 & 2016 & 2017 & 2016 & 2017 \\
\hline April & 22.0 & 17.9 & 5.7 & 4.1 & 13.8 & 10.7 & 47.4 & 52.4 & 23.8 & 29.0 \\
\hline May & 21.6 & 22.1 & 9.1 & 8.9 & 14.9 & 15.2 & 63.7 & 59.5 & 98.0 & 49.9 \\
\hline June & 28.2 & 27.8 & 13.9 & 13.9 & 21 & 20.7 & 53.0 & 54.3 & 16.1 & 18.4 \\
\hline July & 31.4 & 33.1 & 16.7 & 18.0 & 24.2 & 26.0 & 42.5 & 36.0 & 5.8 & 0.4 \\
\hline August & 33.3 & 32.5 & 18.5 & 18.4 & 25.7 & 25.6 & 43.8 & 43.2 & 0.0 & 16.0 \\
\hline Mean/Total & 27.3 & 26.68 & 12.78 & 12.66 & 19.92 & 19.64 & 50.08 & 49.08 & 143.7 & 113.7 \\
\hline
\end{tabular}


The data were subjected to the analysis of variance using the MSTAT-C software based on the experimental design of split plots in randomized blocks (Russell, 1986). The differences between the treatments were grouped according to LSD multiple comparison test $(\mathrm{P} \leq 0.05)$.

\section{RESULTS AND DISCUSSION}

Beside of insignificant effect of inter row spacing on stem thickness, plant height in 2017, flowering and harvest maturity days in both years were statistically affected by intra-row spacing $(\mathrm{P} \leq 0.01)$. Narrowing row spacing increased plant height, caused early flowering and harvest maturity. The effects of intrarow spacing on plant height, stem thickness, flowering and maturation days were statistically significant $(\mathrm{P} \leq 0.01)$ (Table 4).

The increase in row spacing caused a decrease in plant height and an increase in stem thickness. The highest plant was obtained with $20 \mathrm{~cm}$ intra-row spacing. The increase in plant density per unit area caused an increase in plant height and a decrease in stem thickness. The narrower intra row spacing led to early flowering and maturation. Early flowering in arid conditions has a significant effect on yield due to the decrease in precipitation after July. The higher and more regular rainfall distribution in 2016 compared to that in 2017 had positive effects on the morphological and physiological characteristics and led to the difference between the years. The plants were higher in dense sowing due to light competition; however, stem thickness of plants was lower because of the shortage of nutrient and water per unit area. The increase in plant sowing density has also caused stress in plants, resulting early flowering and physiological maturity. The results of current study are agree with those reported by Esechie et al. (1996); Allam et al. (2003) and Ibrahim and El-Genbehy (2009). The head diameter, number of seeds in a head and thousandseed weight which are considered as the main yield criteria, which were affected by the change in interrow and intra row spacings. Whereas, the dehulled seed ratio was only affected by the different intra row spacing (Table 5).

The inter row spacing $70 \mathrm{~cm}$ gave better results. The lowest head diameter $(16.33$ and $15.67 \mathrm{~cm})$, seed number (555.34 and 442.72 units), thousand-seed weight $(58.26$ and $53.93 \mathrm{~g})$ and dehulled seed ratio (68.72 and $68.55 \%$ ) in the interrow spacing change were obtained by $20 \mathrm{~cm}$ intra row spacing (Table 5). These values obtained in 2016 were higher than in 2017.The increase in the number of plants per unit area had the negative effects on the head diameter, seed number, thousand-seed weight and dehulled seed ratio. The weakness in head growth negatively affected seed number, thousand-seed weight and seed filling ability. This result is attributed to the increase in plant population, inadequate soil water, the decrease in photosynthesis and the difficulty in nutrient uptake, especially from head formation to seed filling period dry seasons or arid conditions. The deposition of dry matter required to ensure adequate growth and development in sunflower depends on the availability of water in the soil during plant growth, therefore sparse sowing should be preferred to reduce the stress in drought season. When compared two years results, the extra 5.4 $\mathrm{mm}$ precipitation during flowering and seed filling periods (July) in 2016 caused increases in head diameter $(4.2 \%)$, number of seeds $(25.4 \%)$, thousand-seed weight $(8.03 \%)$ and dehulled seed ratio $(0.25 \%)$ in $20 \mathrm{~cm}$ intra row spacing which had the highest plant population.

The highest seed number in both years was obtained from the $70 \times 40$ and $70 \times 35 \mathrm{~cm}$ row spacings where the plant population was the lowest. Increased plant density per unit area adversely affected head growth (Fig. 1). A significant positive correlation $(\mathrm{r}=0.843)$ was obtained between the head diameter and the number of seeds (Figure 2). This result indicated that head diameter was between $16-20 \mathrm{~cm}$ and the number of seeds per head was between $500-700$ seeds. Head formation and seed filling stages are considered as main factors determining the yield. Unfortunately, in this period, in arid conditions where only rainfall-based agricultural systems can be used for crop production, decrease in available soil water, increase in temperature and increased evaporation are major obstacles for plant growth. The effects of inter row, intra row spacing, and inter $\mathrm{x}$ intra row spacing interaction on plant yield and yield were significant for both years (Table 6, $\mathrm{P} \leq 0.01$ )

The plant yield was increased by increased inter $\&$ intra row spacings in which the number of plants per unit area decreased. The plant yield was also adversely affected by plant density in parallel with the head diameter, the seed number per head and the thousandseed weight. Plant yield depends on the genotypic characteristics of the species and all environmental conditions from plant emergence until maturation. Precipitation and temperature are the major factors limiting the yield in arid conditions, but the regular distribution of temperature and rainfall during important growth stages of the plant is, also, very important. Well distributed rainfall, and the steady temperature rise in 2016 compared to that of 2017 did not create any stress conditions to the plants hence, 2016 yield was higher. The effect of changes of inter\&intra row spacing on seed yield was in the opposite direction compared to the plant yield. A higher yield was obtained at $50 \mathrm{~cm}$ interrow and $20-25 \mathrm{~cm}$ intra row spacings where the plant density was high. The difference between yield and plant yield was resulted from higher plant population harvested in the unit area. Contradictory findings for negative effects of dense sowing on yield can be attributed to inability of plants to sufficiently benefit from this area despite the decrease in plant population in arid conditions. The 
results indicated that soil characteristics and distribution of climatic parameters during the growth stages instead of the general approach should be taken into consideration for the decision of dense or sparse sowing. Unexpected Table 4. The effects of inter-row and intra-row spacing on increase in temperature and decrease in precipitation particularly between the head formation and seed filling stages of sunflower ensure the dense sowing favourable.

\begin{tabular}{|c|c|c|c|c|c|c|c|c|}
\hline \multirow[b]{2}{*}{ VS/Parameters } & \multicolumn{2}{|c|}{ Plant height (cm) } & \multicolumn{2}{|c|}{ Stem thickness (mm) } & \multicolumn{2}{|c|}{ Days to flowering (day) } & \multicolumn{2}{|c|}{ Days to maturity (day) } \\
\hline & 2016 & 2017 & 2016 & 2017 & 2016 & 2017 & 2016 & 2017 \\
\hline \multicolumn{9}{|c|}{ Inter Row Space (A) } \\
\hline 50 & 151.17 & $125.28^{\mathrm{a}}$ & 17.28 & 18.44 & $61.33^{\mathrm{b}}$ & $57.33^{\mathrm{b}}$ & $131.93^{b}$ & $119.20^{\mathrm{b}}$ \\
\hline 70 & 151.33 & $122.61^{\mathrm{b}}$ & 17.82 & 18.81 & $65.13^{\mathrm{a}}$ & $61.13^{\mathrm{a}}$ & $135.87^{\mathrm{a}}$ & $124.73^{\mathrm{a}}$ \\
\hline Mean & 151.25 & 123.95 & 17.55 & 18.62 & 63.23 & 59.23 & 133.90 & 121.97 \\
\hline \multicolumn{9}{|c|}{ Intra Row Space(B) } \\
\hline 20 & $154.40^{\mathrm{a}}$ & $129.10^{\mathrm{a}}$ & $16.51^{\mathrm{c}}$ & $17.62^{\mathrm{c}}$ & $61.17^{\mathrm{d}}$ & $57.17^{\mathrm{d}}$ & $131.33^{\mathrm{d}}$ & $119.33^{\mathrm{d}}$ \\
\hline 25 & $151.37^{\mathrm{b}}$ & $125.27^{\mathrm{b}}$ & $16.90^{\mathrm{c}}$ & $18.02^{\mathrm{bc}}$ & $62.17^{\mathrm{c}}$ & $58.17^{\mathrm{c}}$ & $132.00^{\mathrm{d}}$ & $120.83^{\mathrm{c}}$ \\
\hline 30 & $150.57^{\mathrm{b}}$ & $122.75^{\mathrm{bc}}$ & $17.73^{\mathrm{b}}$ & $18.68^{\mathrm{b}}$ & $63.33^{\mathrm{b}}$ & $59.33^{\mathrm{b}}$ & $134.00^{\mathrm{c}}$ & $122.00^{\mathrm{b}}$ \\
\hline 35 & $150.10^{\mathrm{b}}$ & $122.00^{\mathrm{c}}$ & $17.84^{\mathrm{b}}$ & $18.94^{\mathrm{ab}}$ & $64.00^{\mathrm{b}}$ & $60.00^{\mathrm{b}}$ & $135.17^{b}$ & $122.83^{\mathrm{b}}$ \\
\hline 40 & $149.83^{b}$ & $120.62^{\mathrm{c}}$ & $18.77^{\mathrm{a}}$ & $19.86^{\mathrm{a}}$ & $65.50^{\mathrm{a}}$ & $61.50^{\mathrm{a}}$ & $137.00^{\mathrm{a}}$ & $124.83^{\mathrm{a}}$ \\
\hline \multirow{2}{*}{\multicolumn{9}{|c|}{ Interaction $\left(A^{*} B\right)$}} \\
\hline & & & & & & & & \\
\hline $50 * 20$ & 155.20 & 132.53 & 16.32 & 17.15 & 59.67 & 55.67 & 129.67 & 116.33 \\
\hline $50 * 25$ & 151.67 & 127.47 & 16.67 & 17.62 & 60.67 & 56.67 & 129.67 & 118.00 \\
\hline $50 * 30$ & 150.20 & 123.77 & 17.53 & 17.90 & 61.33 & 57.33 & 132.33 & 119.33 \\
\hline $50 * 35$ & 149.47 & 122.53 & 17.38 & 18.91 & 61.67 & 57.67 & 133.33 & 120.00 \\
\hline $\mathbf{5 0} 40$ & 149.33 & 120.10 & 18.47 & 20.60 & 63.33 & 59.33 & 134.67 & 122.33 \\
\hline $70 * 20$ & 153.60 & 125.67 & 16.69 & 18.08 & 62.67 & 58.67 & 133.00 & 122.33 \\
\hline $70 * 25$ & 151.07 & 123.07 & 17.13 & 18.43 & 63.67 & 59.67 & 134.33 & 123.67 \\
\hline $70 * 30$ & 150.93 & 121.73 & 17.94 & 19.46 & 65.33 & 61.33 & 135.67 & 124.67 \\
\hline $70 * 35$ & 150.73 & 121.47 & 18.29 & 18.97 & 66.33 & 62.33 & 137.00 & 125.67 \\
\hline $70^{*} 40$ & 150.33 & 121.13 & 19.07 & 19.11 & 67.67 & 63.67 & 139.33 & 127.33 \\
\hline
\end{tabular}

${ }^{*},{ }^{* *}$ significant at the 0.05 and 0.01 level, respectively. For each main effect, values within columns followed by the same letter are not significant. ns, nonsignificant. V.S.: variation source.

Table 5. The effects of inter-row and intra row spacings on head diameter (HD), number of seeds per head (NSH), thousand-seed weight (TSW) and dehulled seed ratio (DHSR).

\begin{tabular}{|c|c|c|c|c|c|c|c|c|}
\hline \multirow{2}{*}{$\begin{array}{l}\text { VS/Parameter } \\
\text { s } \\
\text { Inter Row Spac }\end{array}$} & \multicolumn{2}{|c|}{$\begin{array}{l}\text { Head diameter } \\
(\mathrm{cm})\end{array}$} & \multicolumn{2}{|c|}{$\begin{array}{c}\text { Number of seeds per } \\
\text { head }\end{array}$} & \multicolumn{2}{|c|}{$\begin{array}{l}\text { Thousand-seed weight } \\
\text { (g) }\end{array}$} & \multicolumn{2}{|c|}{$\begin{array}{c}\text { Dehulled seed ratio } \\
(\%)\end{array}$} \\
\hline & & & & & & & & \\
\hline 50 & $18.21^{\mathrm{b}}$ & $17.40^{\mathrm{b}}$ & $588.74^{\mathrm{b}}$ & $502.80^{\mathrm{b}}$ & $61.22^{\mathrm{b}}$ & 57.58 & 72.93 & 71.06 \\
\hline 70 & $18.92^{\mathrm{a}}$ & $18.19^{\mathrm{a}}$ & $691.07^{\mathrm{a}}$ & $586.84^{\mathrm{a}}$ & $66.37^{\mathrm{a}}$ & 58.94 & 73.22 & 72.68 \\
\hline Mean & 18.56 & 17.79 & 639.91 & 544.82 & 63.80 & 58.26 & 73.07 & 71.87 \\
\hline \multicolumn{9}{|c|}{ Intra Row Space (B) } \\
\hline 20 & $16.33^{\mathrm{e}}$ & $15.67^{\mathrm{d}}$ & $555.34^{\mathrm{e}}$ & $442.72^{\mathrm{e}}$ & $58.26^{\mathrm{d}}$ & $53.93^{\mathrm{c}}$ & $68.72^{\mathrm{d}}$ & $68.55^{\mathrm{d}}$ \\
\hline 25 & $17.47^{\mathrm{d}}$ & $16.70^{\mathrm{c}}$ & $582.39^{\mathrm{d}}$ & $479.17^{\mathrm{d}}$ & $62.21^{\mathrm{c}}$ & $57.94^{\mathrm{b}}$ & $71.66^{\mathrm{c}}$ & $70.33^{\mathrm{cd}}$ \\
\hline 30 & $18.84^{\mathrm{c}}$ & $17.87^{\mathrm{b}}$ & $624.55^{\mathrm{c}}$ & $573.93^{\mathrm{c}}$ & $65.04^{\mathrm{b}}$ & $57.00^{\mathrm{b}}$ & $73.01^{\mathrm{bc}}$ & $72.17^{\mathrm{bc}}$ \\
\hline 35 & $19.66^{\mathrm{b}}$ & $19.22^{\mathrm{a}}$ & $690.75^{\mathrm{b}}$ & $590.12^{\mathrm{b}}$ & $66.15^{\mathrm{ab}}$ & $59.32^{\mathrm{b}}$ & $74.53^{\mathrm{b}}$ & $73.20^{\mathrm{ab}}$ \\
\hline 40 & $20.51^{\mathrm{a}}$ & $19.51^{\mathrm{a}}$ & $746.51^{\mathrm{a}}$ & $638.18^{\mathrm{a}}$ & $67.31^{\mathrm{a}}$ & $63.12^{\mathrm{a}}$ & $77.45^{\mathrm{a}}$ & $75.12^{\mathrm{a}}$ \\
\hline LSD $(P \leq 0.05)$ & 0.516 & 0.546 & 14.61 & 15.20 & 1.289 & 2.766 & 2.073 & 2.618 \\
\hline \multicolumn{9}{|c|}{ Interaction $\left(\mathbf{A}^{*} \mathbf{B}\right)$} \\
\hline $50 * 20$ & 15.87 & 15.13 & $511.78 \mathrm{f}$ & $376.16 \mathrm{~g}$ & 56.61 & 52.93 & 68.45 & 66.27 \\
\hline $50 * 25$ & 16.93 & 16.40 & $555.46 \mathrm{e}$ & $425.74 \mathrm{f}$ & 59.14 & 58.05 & 71.92 & 68.97 \\
\hline $50 * 30$ & 18.82 & 17.73 & $564.37 \mathrm{e}$ & $534.38 \mathrm{~cd}$ & 62.66 & 56.96 & 73.00 & 71.45 \\
\hline $50 * 35$ & 19.22 & 18.70 & $605.09 \mathrm{~d}$ & $555.51 \mathrm{c}$ & 63.54 & 58.00 & 74.23 & 73.07 \\
\hline $50 * 40$ & 20.21 & 19.03 & $706.99 \mathrm{~b}$ & $622.23 b$ & 64.14 & 61.97 & 77.05 & 75.56 \\
\hline $70 * 20$ & 16.80 & 16.20 & $598.89 \mathrm{~d}$ & $509.27 \mathrm{e}$ & 59.91 & 54.94 & 68.99 & 70.84 \\
\hline $70 * 25$ & 18.00 & 17.00 & $609.32 \mathrm{~d}$ & $532.59 \mathrm{~d}$ & 65.28 & 57.84 & 71.40 & 71.69 \\
\hline $70 * 30$ & 18.86 & 18.00 & $684.73 \mathrm{c}$ & $613.48 \mathrm{~b}$ & 67.41 & 57.03 & 73.01 & 72.89 \\
\hline $70 * 35$ & 20.10 & 19.73 & $776.40 \mathrm{a}$ & $624.73 \mathrm{~b}$ & 68.77 & 60.64 & 74.83 & 73.33 \\
\hline
\end{tabular}




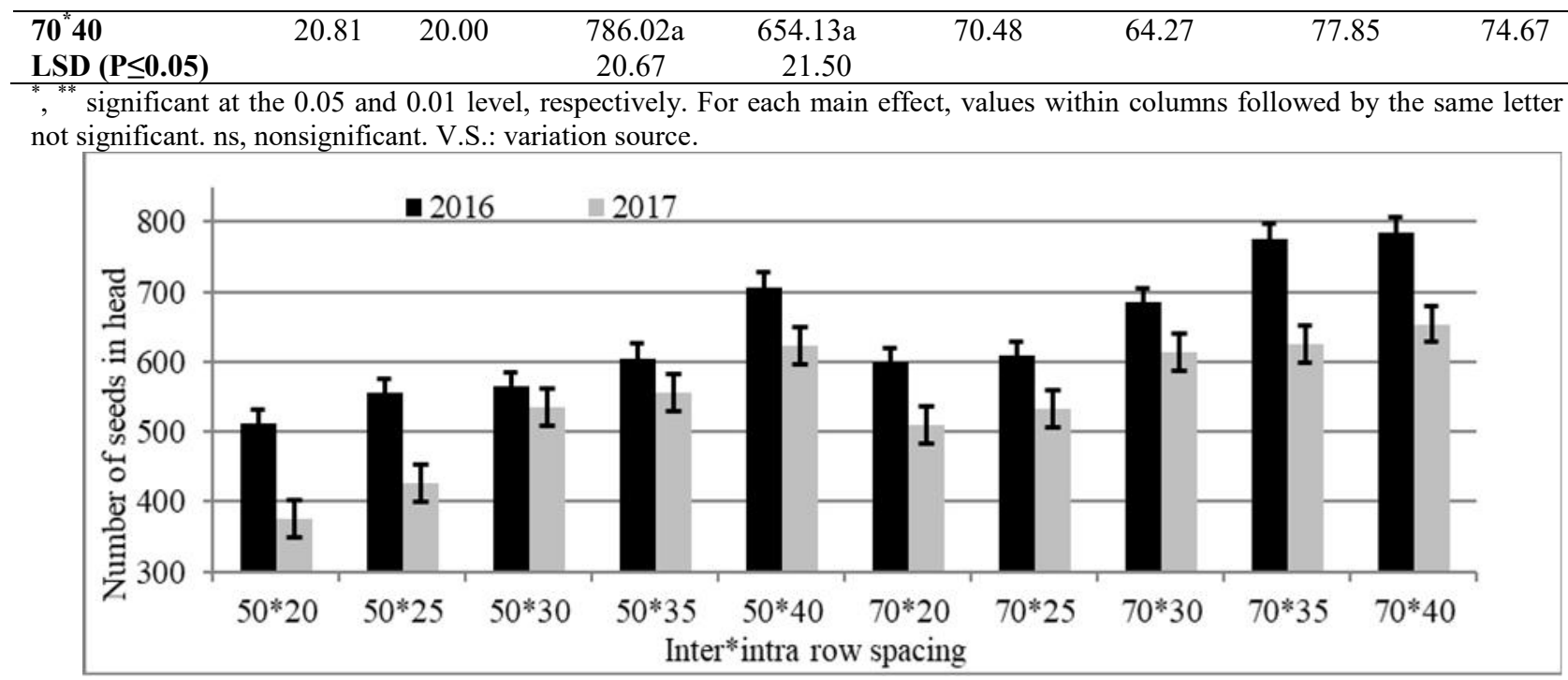

Figure 1. The interaction between seed number per head and inter:intra row spacing.

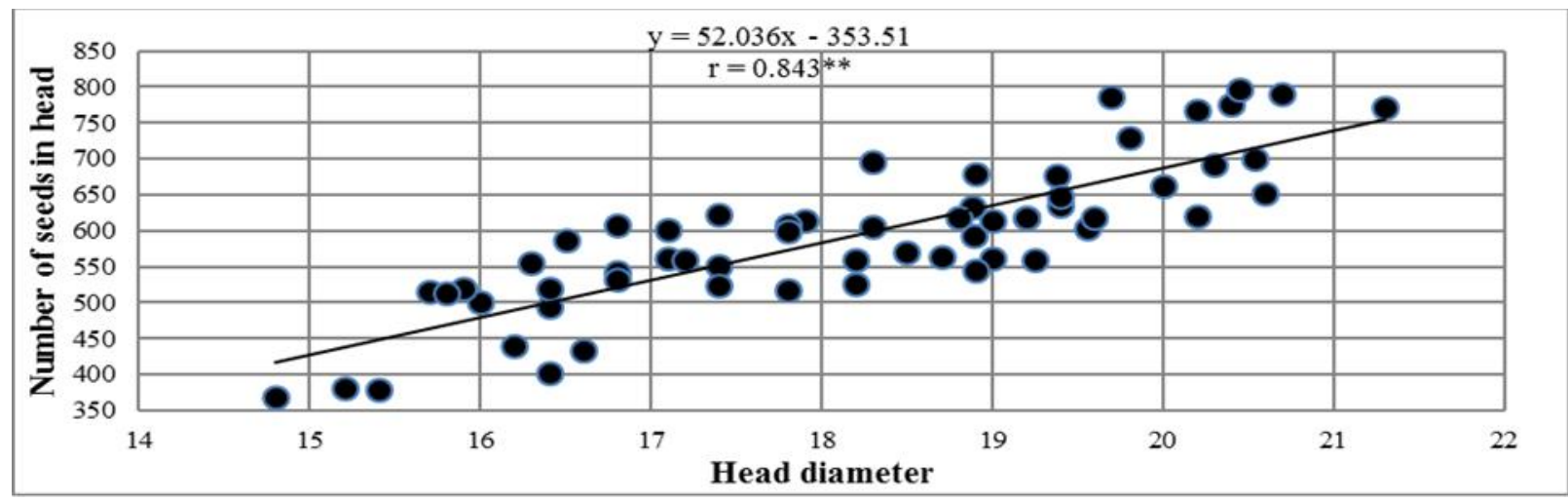

Figure 2. Relation between head diameter and seed number per head, $\mathrm{r}=$ coefficient of correlation, ${ }^{* *}: \mathrm{P} \leq 0.01$

Table 6. The effects of inter-row and intra row spacings on seed weight of per plant (g), seed yield $\left(\mathrm{kg} \mathrm{ha}^{-1}\right)$, crude oil rate $(\%)$, oil yield $\left(\mathrm{kg} \mathrm{ha}^{-1}\right)$.

\begin{tabular}{|c|c|c|c|c|c|c|c|c|}
\hline & \multicolumn{2}{|c|}{ Seed weight of per plant (g) } & \multicolumn{2}{|c|}{ Seed yield $\left(\mathrm{kg} \mathrm{ha}^{-1}\right)$} & \multicolumn{2}{|c|}{ Crude oil rate (\%) } & \multicolumn{2}{|c|}{ Oil yield $\left(\mathrm{kg} \mathrm{ha}^{-1}\right)$} \\
\hline VS/Parameters & 2016 & 2017 & 2016 & 2017 & 2016 & 2017 & 2016 & 2017 \\
\hline \multicolumn{9}{|c|}{ Inter Row Space (A) } \\
\hline 50 & $37.02^{\mathrm{b}}$ & $29.38^{\mathrm{b}}$ & $2391.29^{\mathrm{a}}$ & $1750.93^{\mathrm{a}}$ & 47.26 & 46.05 & $1129.37^{\mathrm{a}}$ & $806.36^{\mathrm{a}}$ \\
\hline 70 & $44.96^{\mathrm{a}}$ & $34.87^{\mathrm{a}}$ & $2007.10^{\mathrm{b}}$ & $1596.41^{\mathrm{b}}$ & 46.97 & 46.66 & $942.12^{\mathrm{b}}$ & $741.79^{b}$ \\
\hline Mean & 40.99 & 32.12 & 2199.20 & 1673.67 & 47.11 & 46.35 & 1035.75 & 774.08 \\
\hline \multicolumn{9}{|c|}{ Intra Row Space (B) } \\
\hline 20 & $33.08^{\mathrm{d}}$ & $24.37^{\mathrm{e}}$ & $2618.78^{a}$ & $1833.02^{\mathrm{a}}$ & 46.65 & $44.94^{\mathrm{b}}$ & $1221.92^{\mathrm{a}}$ & $824.33^{\mathrm{a}}$ \\
\hline 25 & $37.30^{\mathrm{c}}$ & $28.13^{\mathrm{d}}$ & $2466.12^{\mathrm{a}}$ & $1850.27^{\mathrm{a}}$ & 47.00 & $45.63^{\mathrm{b}}$ & $1159.68^{\mathrm{a}}$ & $844.18^{\mathrm{a}}$ \\
\hline 30 & $41.46^{\mathrm{b}}$ & $33.16^{\mathrm{c}}$ & $2122.58^{b}$ & $1584.05^{\mathrm{b}}$ & 47.16 & $46.81^{\mathrm{a}}$ & $1001.60^{\mathrm{b}}$ & $740.65^{\mathrm{b}}$ \\
\hline 35 & $45.25^{\mathrm{a}}$ & $35.27^{\mathrm{b}}$ & $1990.7^{\mathrm{b}}$ & $1575.47^{\mathrm{b}}$ & 47.29 & $46.95^{\mathrm{a}}$ & $941.58^{\mathrm{b}}$ & $738.53^{b}$ \\
\hline 40 & $47.86^{\mathrm{a}}$ & $39.68^{\mathrm{a}}$ & $1797.8^{\mathrm{c}}$ & $1525.57^{\mathrm{b}}$ & 47.47 & $47.43^{\mathrm{a}}$ & $853.93^{c}$ & $722.68^{b}$ \\
\hline Mean & 40.99 & 32.12 & 2199.20 & 1673.68 & 47.11 & 46.35 & 1035.74 & 774.07 \\
\hline LSD & 3.258 & 1.605 & 167.30 & 76.84 & & 0.723 & 81.95 & 39.44 \\
\hline \multicolumn{9}{|c|}{ Interaction $\left(A^{*} B\right)$} \\
\hline $50 * 20$ & $30.28^{\mathrm{e}}$ & $19.72^{\mathrm{h}}$ & $2759.87^{\mathrm{a}}$ & $1702.20^{\mathrm{d}}$ & 46.74 & 44.65 & 1290.10 & $760.23^{\mathrm{c}}$ \\
\hline $50 * 25$ & $35.03^{\mathrm{d}}$ & $24.71^{\mathrm{g}}$ & $2704.8^{\mathrm{ab}}$ & $1816.67^{\mathrm{bd}}$ & 47.23 & 45.99 & 1277.67 & $835.57^{\mathrm{ab}}$ \\
\hline
\end{tabular}




\begin{tabular}{|c|c|c|c|c|c|c|c|c|}
\hline $50 * 30$ & $37.88^{d}$ & $30.41^{\text {ef }}$ & $2400.2^{\mathrm{cd}}$ & $1764.3^{\mathrm{cd}}$ & 47.20 & 46.26 & 1133.80 & $816.23^{b c}$ \\
\hline $50 * 35$ & $38.03^{\mathrm{d}}$ & $33.46^{\mathrm{d}}$ & $2037.57^{\mathrm{ef}}$ & $1762.27^{\mathrm{cd}}$ & 47.43 & 46.29 & 966.17 & $815.93^{b c}$ \\
\hline $50 * 40$ & $43.86^{b c}$ & $38.60^{\mathrm{ab}}$ & $2054.03^{\mathrm{ef}}$ & $1709.23^{\mathrm{cd}}$ & 47.68 & 47.03 & 979.10 & $803.83^{b c}$ \\
\hline $70 * 20$ & $35.87^{\mathrm{d}}$ & $29.02^{f}$ & $2477.70^{b c}$ & $1963.83^{\mathrm{a}}$ & 46.56 & 45.22 & 1153.73 & $888.43^{\mathrm{a}}$ \\
\hline $70 * 25$ & $39.57^{\mathrm{cd}}$ & $31.56^{\mathrm{de}}$ & $2227.43^{\mathrm{de}}$ & $1883.87^{\mathrm{ab}}$ & 46.76 & 45.27 & 1041.70 & $852.80^{\mathrm{ab}}$ \\
\hline $70 * 30$ & $45.04^{\mathrm{b}}$ & $35.92^{c}$ & $1844.97^{f}$ & $1403.80^{\mathrm{e}}$ & 47.11 & 47.37 & 869.40 & $665.07^{\mathrm{d}}$ \\
\hline $70 * 35$ & $52.48^{\mathrm{a}}$ & $37.08^{b c}$ & $1943.83^{f}$ & $1388.67^{\mathrm{e}}$ & 47.16 & 47.61 & 917.00 & $661.13^{d}$ \\
\hline $70^{*} 40$ & $51.86^{\mathrm{a}}$ & $40.76^{\mathrm{a}}$ & $1541.57^{\mathrm{g}}$ & $1341.90^{\mathrm{e}}$ & 47.25 & 47.82 & 728.77 & $64.153^{d}$ \\
\hline LSD & 4.607 & 2.270 & 236.61 & 108.72 & & & & 68.32 \\
\hline
\end{tabular}

${ }^{*},{ }^{* *}$ significant at the 0.05 and 0.01 level, respectively. For each main effect, values within columns followed by the same letter are not significant. ns, nonsignificant. V.S.: variation source.

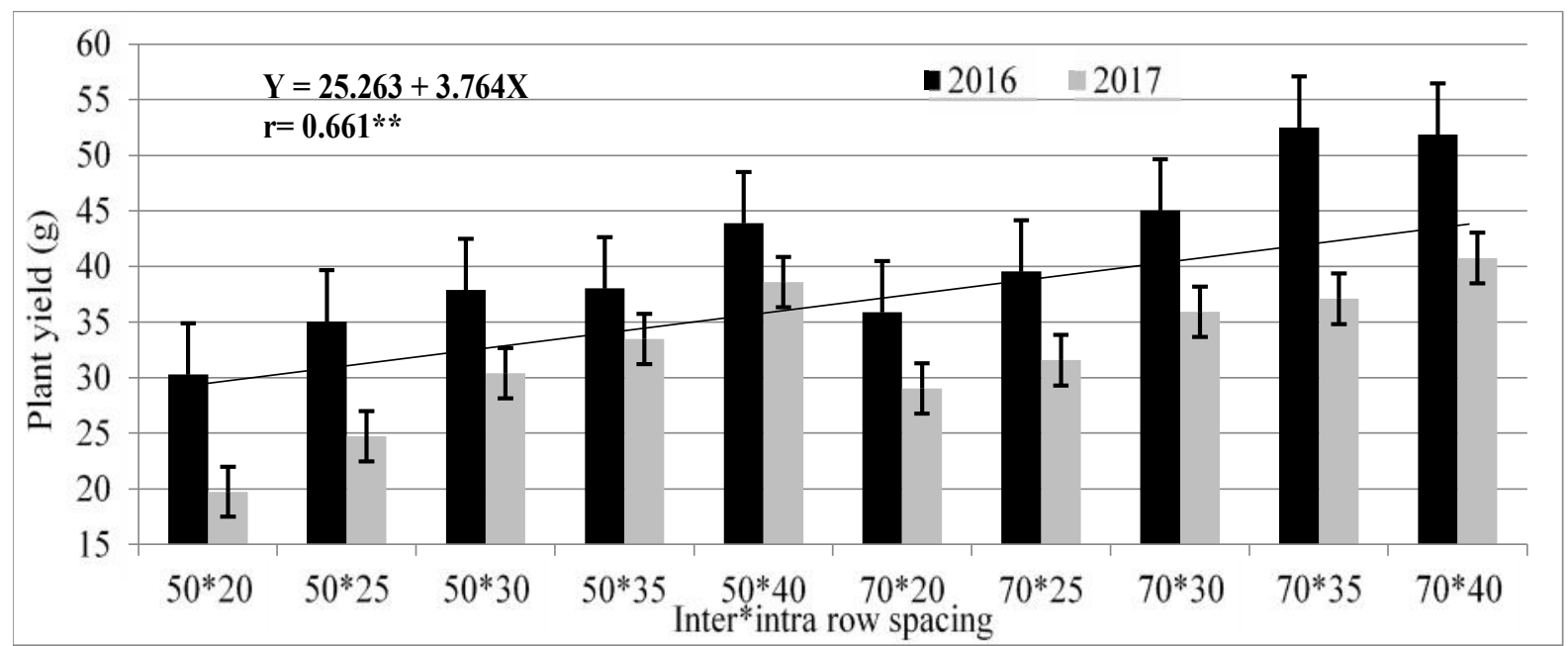

Figure 3. The interaction between inter\&intra row spacing and plant yield, $r=$ coefficient of correlation, ${ }^{* *}: P \leq 0.01$.

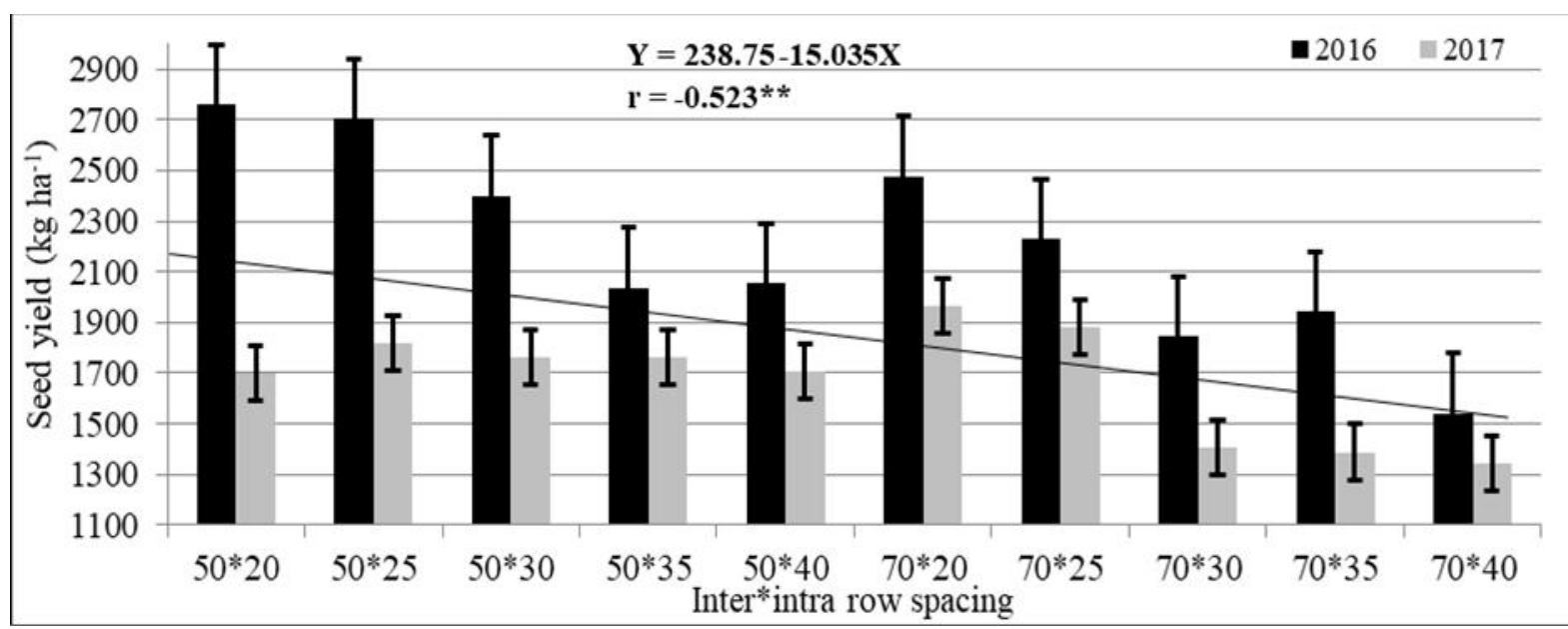

Figure 4. The interaction between inter and intra row spacing and seed yield, $r=$ coefficient of correlation, ${ }^{* *}: P \leq 0.01$

The interactions between interrow and intra row spacings revealed a significant positive relationship $(\mathrm{r}=0.661, \mathrm{P} \leq 0.01)$ between plant yield and interrow and intra row spacings (Figure 3). The higher plant yields were obtained from $70 \times 35,70 \times 40$ and $50 \times 40 \mathrm{~cm}$ interrow and intra row spacings. In contrast to the relationship between plant yield and seed yield, a significantly negative relationship $(\mathrm{r}=-0.523, \mathrm{P} \leq 0.01)$ was obtained between inter\&intra row spacings (Figure 4). An increase in plant density resulted to increased yield per unit area. The increased yield per plant by increasing interrow spacing was efficient way to increase yield, considering the tolerance of sunflower to arid conditions. The higher yields were obtained from $50 \times 20,50 \times 25$ and $70 \times 20 \mathrm{~cm}$ row spacings. Significant differences in seed yields can be associated with temperature and precipitation 
parameters. Irregular and low rainfall in 2017 adversely affected yield parameters despite the regular and high rainfall in 2016. The higher seed yields in 2016 and 2017 were 2759.87 and $1963.83 \mathrm{~kg} \mathrm{ha}^{-1}$ which were obtained from $50 \times 20 \mathrm{~cm} 70 \times 20 \mathrm{~cm}$ sowing distances, respectively. The lower seed yields were determined as $1541.57 \mathrm{~kg} \mathrm{ha}^{-}$ 1 and $1341.90 \mathrm{~kg} \mathrm{ha}^{-1}$ from the $70 \times 40 \mathrm{~cm}$ sowing distance. The findings reported by Ibrahim (2012) and Ion et al. (2015) were in line with the results of our study. The effect of change in interrow spacing on crude oil ratio was statistically insignificant. The oil ratio in 2017 significantly increased by enhanced intra row spacing $(\mathrm{P} \leq 0.01)$. The oil yield was significantly affected by the changes of inter\&intra row spacing in both years $(\mathrm{P} \leq 0.01)$. This change in oil yield, most likely, is not related to the change in oil ratio, but rather due to changes in seed yield. The higher oil yields in both years were obtained from $50 \mathrm{~cm}$ interrow and $20-25 \mathrm{~cm}$ intra row spacings. Higher oil yield was obtained in the dense sowing due to the increase in the number of plants, despite a slight decrease in the oil content. The interactions between oil yield and inter\&intra row spacings showed that the highest oil yield in 2017 was obtained in $70 \times 20 \mathrm{~cm}$ inter\&intra row spacing.

Conclusion and Recommendations: Current study showed that there were significant differences between growth and yield parameters of sunflower, depending upon inter row and intra row spacing. The plant height increased, while the plant stem thickness, head diameter, number of seeds in a head, thousand-seed weight and plant seed yield decreased as inter \& intra row spacing was narrowed. However, plant growth, yield and oil ratio for all sowing spacing were decreased due to water restriction in experimental area during growing period. In order to minimize the detrimental effects of erratic rainfall, $50 \times 25 \mathrm{~cm}$ inter and intra row spacing is recommended for higher seed yield in sunflower under rainfed conditions.

\section{REFERENCES}

Ahmad, M., A. Khaliq, R. Ahmad, and A. M. Ranjha. (2010). Allometery and productivity of autumn planted maize hybrids under narrow row spacing. Int. J. Agric. Biol 12:661-667.

Allam, A., G. El-Nagar, and A. Galal. (2003). Response of two sunflower hybrids to planting dates and densities. Acta Agronomica Hungarica 51(1):2535.

Beg, A., S. Pourdad, and S. Alipour. (2007). Row and plant spacing effects on agronomic performance of sunflower in warm and semi-cold areas of iran. Helia 30(47):99-104.

Demir, I., and D. Basalma. (2018). Response of different level of nitrogen and sulphur doses on oil yield and seed nutrients content of sunflower (Helianthus annuus L.). Fresenius Environmental Bulletin 27(9):6337-6342.

Diepenbrock, W., M. Long, and B. Feil. (2001). Yield and quality of sunflower as affected by row orientation, row spacing and plant density. Die Bodenkultur 52(1):29-36.

Esechie, H., S. Elias, V. Rodriguez, and H. Al-Asmi. (1996). Response of sunflower (Helianthus annuus) to planting pattern and population density in a desert climate. The J. Agricultural Science 126(4):455-461.

Ibrahim, H., and M. El-Genbehy. (2009). Response of some sunflower hybrids to different hill spacings and $\mathrm{N}$-fertilization levels. Minufiya. J Agric Res 34:641-659.

Ibrahim, H. M. (2012). Response of some sunflower hybrids to different levels of plant density. APCBEE Procedia 4:175-182.

Ion, V., G. Dicu, A. G. Basa, M. Dumbrava, G. Temocico, L. I. Epure, and D. State. (2015). Sunflower yield and yield components under different sowing conditions. Agriculture and Agricultural Science Procedia 6:44-51.

Russell, D. (1986). MSTAT-C package programme. Crop and Soil Science Department, Michigan State University, USA. 